\title{
Perancangan Sistem Efisiensi Penggunaan Energi Listrik Menggunakan Sensor Gerak dan Sensor Arus
}

\author{
Sarmayanta Sembiring ${ }^{1, *}$, Hadir Kaban², Rido Zulfahmi ${ }^{3}$ \\ ${ }^{1}$ Fakultas Ilmu Komputer, Jurusan Sistem Komputer, Universitas Sriwijaya, Indralaya, Indonesia \\ ${ }^{2}$ Fakultas Matematika dan Ilmu Pengetahuan Alam, Jurusan Fisika, Universitas Sriwijaya, Indralaya, Indonesia \\ ${ }^{3}$ Fakultas Ilmu Komputer, Jurusan Informatika, Universitas Pembangunan Nasional, Jakarta, Indonesia \\ Email: 1,*yanta@unsri.ac.id, ${ }^{2}$ hadir_kaban@mipa.unsri.ac.id, ${ }^{3}$ rido.zet@gmail.com \\ Email Penulis Korespondensi: yanta@unsri.ac.id
}

\begin{abstract}
Abstrak-Sistem efisiensi dalam menggunakan energi listrik telah dirancang menggunakan sensor gerak PIR, sensor arus SCT-013-030, LED inframerah dan relay dengan pengendali menggunakan Arduino Uno. Sistem ini dirancang untuk mematikan peralatan elektronik seperti AC, proyektor, dan lampu secara otomatis sebagai solusi dari pengguna yang lupa mematikan peralatan elektronik saat tidak lagi digunakan. Hasil percobaan menunjukkan bahwa sistem telah berjalan dengan baik, di mana sistem dapat mendeteksi tidak ada gerakan untuk waktu yang telah ditentukan dengan menggunakan sensor gerak PIR. Deteksi peralatan elektronik menggunakan sensor SCT-013-030 telah mampu membedakan keadaan peralatan apakah itu ON atau OFF berdasarkan perbedaan dalam data output sensor yang dibaca oleh port analog Arduino. Data sensor saat mendeteksi lampu ketika OFF rata-rata $=1,333$ sedangkan proyektor mini dan TV saat OFF nilai rata-rata data sensor $=$ 1,667. Data sensor arus rata-rata saat mendeteksi lampu saat $\mathrm{ON}=5.333$, proyektor mini $=8.333$ dan $\mathrm{TV}=11.333$. Secara keseluruhan sistem yang dirancang telah mampu mematikan peralatan yang masih aktif ketika sensor tidak mendeteksi pergerakan manusia selama waktu yang telah ditentukan.
\end{abstract}

Kata Kunci: Efisiensi Energi Listrik, Sensor Gerak PIR, Sensor Arus SCT-013-030, Arduino Uno, LED Infra Merah

Abstract-Efficiency system in using electrical energy has been designed using a PIR motion sensor, current sensor SCT013-030, infrared LED and relay with a controller using Arduino Uno. The system is designed to turn off electronic equipment such as air conditioners, projectors and lights automatically as a solution from users forgetting to turn off electronic equipment when it is no longer in use. The experimental results show that the system has been running well, where the system can detect no movement for a predetermined time by using a PIR motion sensor. Detection of electronic equipment using sensors SCT-013-030 has been able to distinguish the state of the equipment whether it is ON or OFF based on differences in sensor output data that is read by the Arduino analog port. Sensor data when detecting the lamp when OFF is average $=1.333$ while the mini projector and TV when off the average sensor data value $=1.667$. The average current sensor data when detecting lights when $\mathrm{ON}=5,333$, mini projector $=8,333$ and $\mathrm{TV}=11,333$. Overall the system designed has been able to turn off the equipment that is still active when the sensor does not detect any human movement during a predetermined time.

Keywords: Electrical Energy Efficiency, PIR Motion Sensor, Current Sensor SCT-013-030, Arduino Uno, Infrared LED

\section{PENDAHULUAN}

Kelas merupakan salah satu ruang dalam perguruan tinggi yang memiliki fasilitas seperi lampu penerangan, kipas angin, Air Conditioner (AC), proyektor, komputer dan lain-lain yang menggunakan energi listrik. Pencahayaan dan pendingin ruang kuliah akan memberikan banyak manfaat bagi pengguna mahasiswa dan dosen. Penggunaan fasilitas didalam kelas secara berlebihan berupa peralatan elektronik sering sekali terjadi dan ini disebabkan pengguna di dalam kelas lupa untuk mematikan peralatan elektronik [1]. Penggunaan listrik secara efisien untuk menurunkan permintaan energi pada sisi konsumen dengan cara mematikan lampu diruangan saat tidak digunakan merupakan salah satu cara yang dapat dilakukan [2]. Berdasarkan permasalahan penggunaan energi listrik yang terbuang sia-sia yang diakibatkan pengguna lupa untuk mematikan peralatan elektronik di dalam kelas saat sudah tidak dipergunakan lagi, peneliti tertarik untuk melakukan penelitian untuk merancang suatu sistem yang dapat menjadi solusi dari pengguna yang "lupa" mematikan peralatan saat sudah tidak dipergunakan lagi, sehingga penggunaan energi listrik dapat efesien.

Beberapa peneliti telah melakukan penelitian terkait masalah efisiensi penggunaan energi listrik, seperti peneliti [3] merancang sebuah sistem pengendalian peralatan elektronik secara otomatis menggunakan pengendali mikrokontriler ATMega16 dengan input dari sensor Passive Infrared (PIR), LM35 dan Light Dependent Resistor (LDR). Peneliti [4] merancang protitipe lampu otomatis dengan menggunakan sensor PIR dan Real Time Clock (RTC) DS3231 berbasis Arduino Uno untuk menghemat pemakaian daya listrik. Peneliti [5] merancang sebuah smart home untuk pengendalian lampu dengan menggunakan kendali arduino untuk mengaktifkan/memutus relay yang terhubung ke lampu berdasarkan informasi LDR yang penempatannya berada diluar rumah. Peneliti [6] Merancang sistem otomatis lampu pada kamar kecil dengan menggunakan sensor PIR, sensor suhu MLX90614 dan sensor suara KY-038. Peneliti [7] merancang kendali otomatis lampu dan pendingin ruangan untuk efisiensi penggunaan daya listrik menggunakan sensor PIR dan LDR. Peneliti [8] Sistem yang dirancang untuk mengendalikan tiga buah lampu dengan menggunakan 2 buah sensor PIR, 1 buah sensor LDR dan 3 buah relay yang dikendalikan oleh arduino uno.

Lupa untuk mematikan peralatan elektronik dalam kelas/ruang saat tidak digunakan lagi merupakan salah satu permasalahan dalam efisiensi penggunaan energi listrik. Otomatisasi dalam penggunaan peralatan elektronik 
merupakan salah satu solusi untuk mengatasi masalah efisiensi penggunaan energi listrik seperti dilakukan peneliti-peneliti sebelumnya. Untuk mengatasi permasalahan tersebut. Sebagai solusi dari lupa mematikan peralatan elektronik yang sudah tidak digunakan di dalam kelas, peneliti mengusulkan sebuah sistem otomatis yang dapat mematikan peralatan dalam kelas seperti lampu, AC dan proyektor yang tidak dipergunakan lagi sebagai solusi pengguna lupa menekan saklar OFF atau menekan tombol OFF pada remote control. Sistem ini diterapkan tanpa merubah fungsi pengendalian konvensional, dimana pengguna tetap dapat menggunakan saklar atau remote control untuk mengendalikan peralatan dalam kelas sesuai dengan kebutuhan. Untuk mengetahui tidak ada orang didalam kelas sebagai informasi ke sistem pengendali untuk mematikan lampu, penulis menggusulkan penggunaan sensor gerak PIR seperti yang digunakan peneliti [3],[4],[6],[7],[8]. dengan pertimbangan sensor ini dapat mendeteksi pergerakan sampai dengan jarak 6 meter [7],[9] dan hasil penelitian [2] menunjukkan dengan pemasangan sensor gerak untuk penerangan, pengurangan konsumsi energi listrik bulanan yang diharapkan adalah antara $30 \%$ dan $40 \%$ lebih rendah dibandingkan dengan yang tanpa pemasangan sensor.

Untuk mematikan peralatan yang menggunakan remote control seperti AC dan proyektor dimana pengendalian ON/OFF berada pada satu tombol remote control, maka selain informasi keadaan kelas sudah tidak digunakan lagi dari sensor PIR dibutuhkan juga informasi keadaan peralatan tersebut dalam keadaan aktif atau standby agar sistem kendali dapat memutuskan perlu tidak transmitter mengirimkan sinyal ON/OFF ke receiver agar tidak terjadi kesalahan seperti peralatan yang dalam keadaan standby menjadi aktif. Informasi keadaan peralatan elektronik dalam keadaan ON atau OFF dapat di deteksi berdasarkan arus yang mengalir ke beban [10], maka selain informasi dari sensor PIR, informasi keadaan peralatan elektronik dalam penelitian ini menggunakan sensor arus dan ini merupakan cara pengendalian peralatan elektronik di dalam kelas yang berbeda dari penelitian sebelumnya. Sensor arus yang digunakan dalam penelitian ini menggunakan sensor arus seri SCT-013 yang merupakan sensor transformator non invasive yang dapat mengukur arus tanpa harus memodifikasi konduktor karena sensor ini memiliki split (seperti penjepit) [11]. Sistem yang dirancang diharapkan dapat menjadi solusi dalam efisiensi penggunaan energi listrik dalam kelas dengan biaya yang murah.

\section{METODE PENELITIAN}

Kerangka kerja metode pelaksanaan penelitian perancangan sistem efisiensi penggunaan energi listrik menggunakan sensor gerak dan sensor arus ditunjukkan pada Gambar 1.

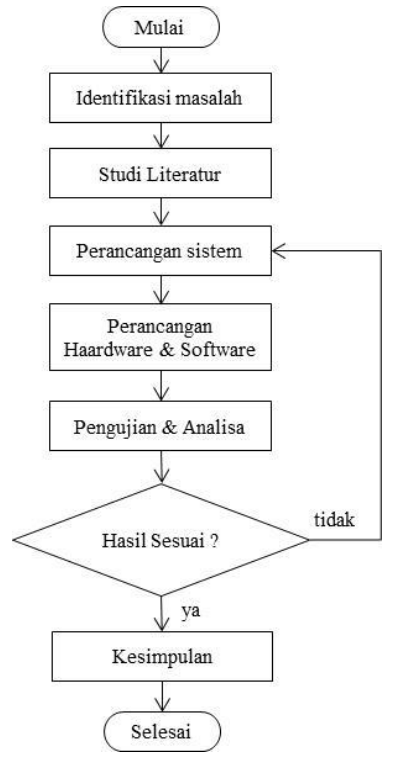

Gambar 1. Kerangka kerja metode pelaksanaan penelitian

Dalam kegiatan penelitian ini dimulai dengan merancang sebuah kerangka kerja, dimana kerangka kerja ini menggambarkan langkah-langkah dalam pelaksanaan penelitian yang akan dilaksanakan secara garis besar.

\subsection{Studi Literatur}

Dengan cara mempelajari berbagai sumber yang berkaitan dengan topik efisiensi penggunaan energi listrik dan otomatisasi pengendalian peralatan elektronik untuk mendapatkan solusi permasalahan yang efektif dan efisien. Studi literatur ini juga bertujuan untuk menentukan hardware dan software yang sesuai dengan kebutuhan dalam merancang sistem efisiensi penggunaan energi listrik untuk mengatasi permasalahan pengguna lupa mematikan peralatan elektronik di dalam kelas/ruang, sehingga sistem yang dirancang dapat sesuai dengan kebutuhan. 
JURNAL MEDIA INFORMATIKA BUDIDARMA

Volume 4, Nomor 3, Juli 2020, Page 626-634

ISSN 2614-5278 (media cetak), ISSN 2548-8368 (media online)

Available Online at https://ejurnal.stmik-budidarma.ac.id/index.php/mib DOI 10.30865/mib.v4i3.2134

\subsection{Perancangan Sistem}

Pada tahap ini dilakukan identifikasi permasalahan banyaknya energi listrik yang terbuang percuma pada saat sudah tidak digunakan lagi pada kelas/ruang. Salah satu faktor yang menyebabkan pengguna tidak mematikan peralatan elektronik dalam kelas/ruang diakibatkan karena "lupa". Perancangan sistem efisiensi penggunaan energi listrik menggunakan sensor gerak dan sensor arus bertujuan untuk mematikan peralatan elektronik seperti AC, proyektor dan lampu dalam ruang kelas saat tidak digunakan lagi sebagai solusi pengguna lupa mematikannya dengan tujuan efesiensi penggunaan energi listrik. Cara kerja yang diusulkan dalam penelitian ini saat sensor PIR tidak mendeteksi pergerakan selama 1 menit dari data pergerakan terakhir yang terdeteksi, maka sistem menyimpulkan ruang kelas dalam keadaan kosong dan sistem mulai melakukan pengecekan keadaan peralatan didalam kelas dimulai dengan mengukur beda arus yang mengalir ke AC jika data yang terdeteksi > data referensi yang ditetapkan, maka sistem akan menyimpulkan AC masih dalam keadaan hidup, lalu sistem akan mengirimkan sinyal ON/OFF melalui PIN 3 ke pemancar Infra merah. Langkah kedua sistem akan melakukan pengecekan keadaan proyektor dengan langkah yang sama dan terakhir melakukan pengecekan pada lampu, jika data yang terdeteksi > data referensi maka sistem akan mengirimkan sinyal melalui PIN 5 untuk memutus arus yang mengalir ke lampu melalui modul relay. Gambar 2 menunjukkan blok diagram perancangan sistem secara keseluruhan.

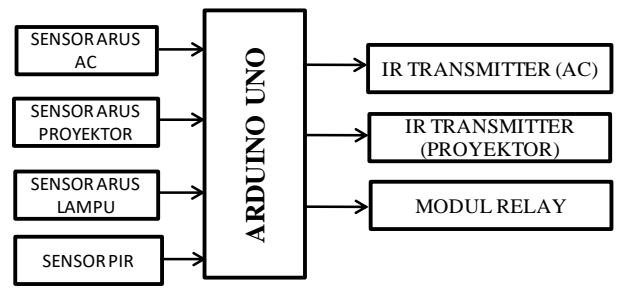

Gambar 2. Blok diagram sistem

Karena tombol ON/OFF pada remote control AC/proyektor dapat berfungsi untuk menghidupkan atau mematikan peralatan dalam satu tombol, sehingga untuk mengendalikan AC/proyektor dalam suatu ruangan perlu diketahui keadaan AC sebelumnya (AC/Proyektor dalam keadaan aktif atau standby) sehingga sistem dapat menentukan aksi yang harus dilakukan. Dalam penelitian ini sensor arus SCT-013-030 digunakan untuk mendeteksi keadaan peralatan berdasarkan beda arus yang mengalir ke peralatan elektronik. Sensor SCT-013030 dapat mendeteksi arus hingga 30A dengan output berupa tegangan $0-1$ Volt [12]. Perbedaan arus yang mengalir pada peralatan elektronik saat aktif/standby akan menyebabkan perbedaan pembacaan data ADC pada Port A0, A1 dan A3 dan menjadi indikator peralatan dalam keadaan aktif/standby. Perancangan sistem ini secara umum terbagi atas 2 bagian, yaitu perancangan hardware dan perancangan software.

\subsection{Perancangan Hardware}

Dalam penelitian ini digunakan sebuah sensor PIR, 3 buah sensor SCT-013-30, 2 buah LED infra merah yang disusun paralel, 1 buah relay dan 1 buah push button. 3 buah sensor arus digunakan untuk mendeteksi peralatan AC, proyektor dan lampu, sensor PIR untuk mendeteksi keadaan kelas/ruangan, 2 buah LED infra merah digunakan untuk mengirimkan sinyal ON/OFF ke receiver AC dan proyektor. Push button digunakan untuk tombol ON/OFF lampu. Gambar 3 menunukkan secara lengkap rangkaian secara keseluruhan.

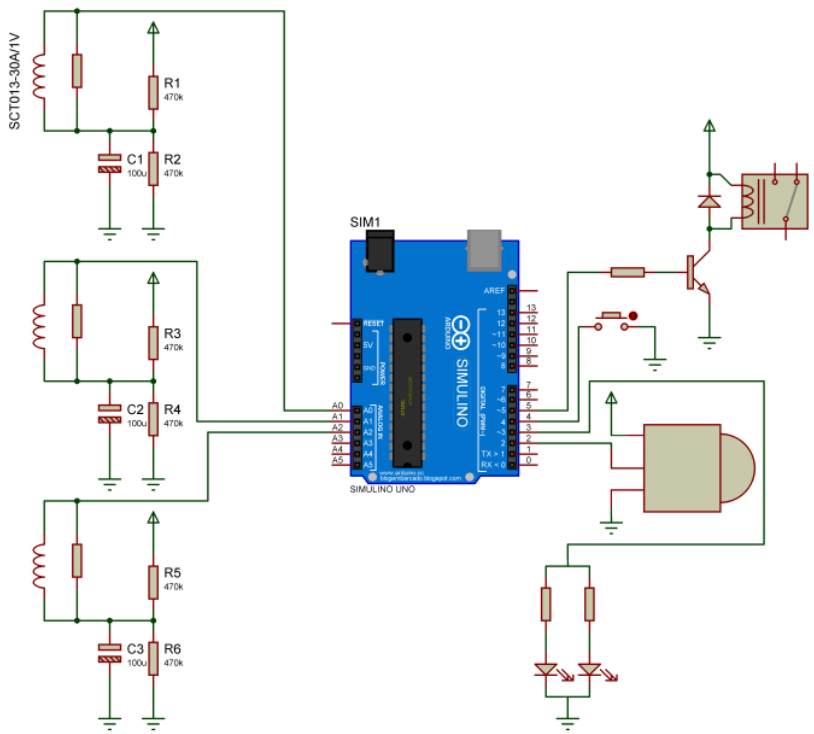

Gambar 3. Rangkaian secara keseluruhan 


\subsection{Perancangan Software}

Untuk mengetahui tidak ada pergerakan yang terdeteksi sensor PIR selama waktu yang ditentukan sebagai indikator ruang kelas telah kosong dalam penelitian ini penulis menggunakan output sensor PIR sebagai trigger untuk menjalankan interupsi dan menggunakan fungsi millis yang terdapat pada arduino. Gambar 4(A) menunjukkan flowchart pendeteksi ruang kelas.

Pendeteksi keadaan peralatan didalam kelas seperti AC, proyektor dan lampu menggunakan sensor SCT-013030, Jika data dari sensor arus melebihi nilai referensi yang ditentukan maka sistem akan menyimpulkan peralatan tersebut dalam keadaan aktif dan sebaliknya jika data sensor arus yang terdeteksi $\leq$ referensi maka sistem menyimpulkan peralatan dalam keadaan OFF/standby. Gambar 4(B) menunjukkan flowchart pendeteksi arus peralatan didalam ruang kelas dengan menggunakan tiga buah sensor SCT-013-30 yang terhubung ke port A0 untuk mendeteksi AC, port A1 untuk mendeteksi proyektor dan port A2 untuk mendeteksi lampu.

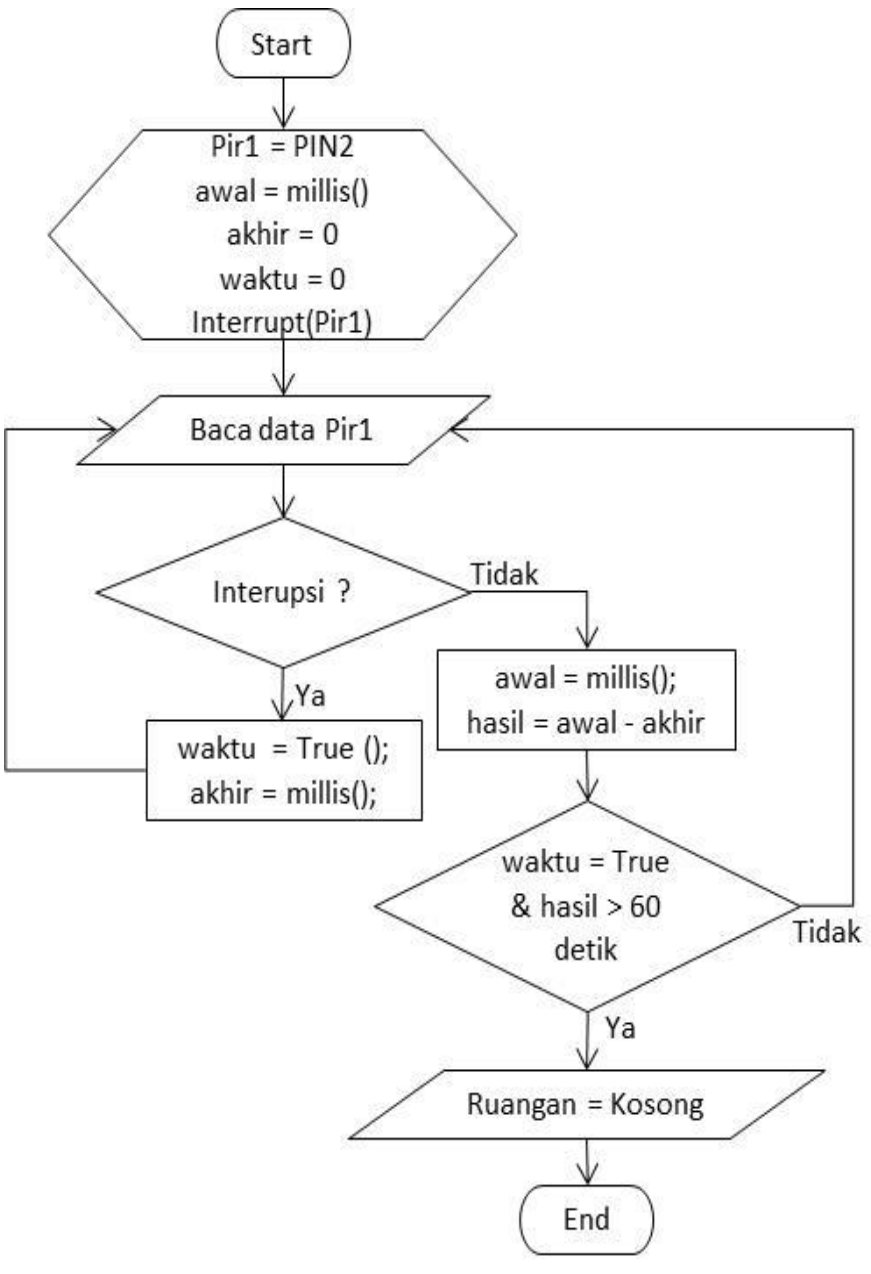

A. Flowchart penditeksi ruang

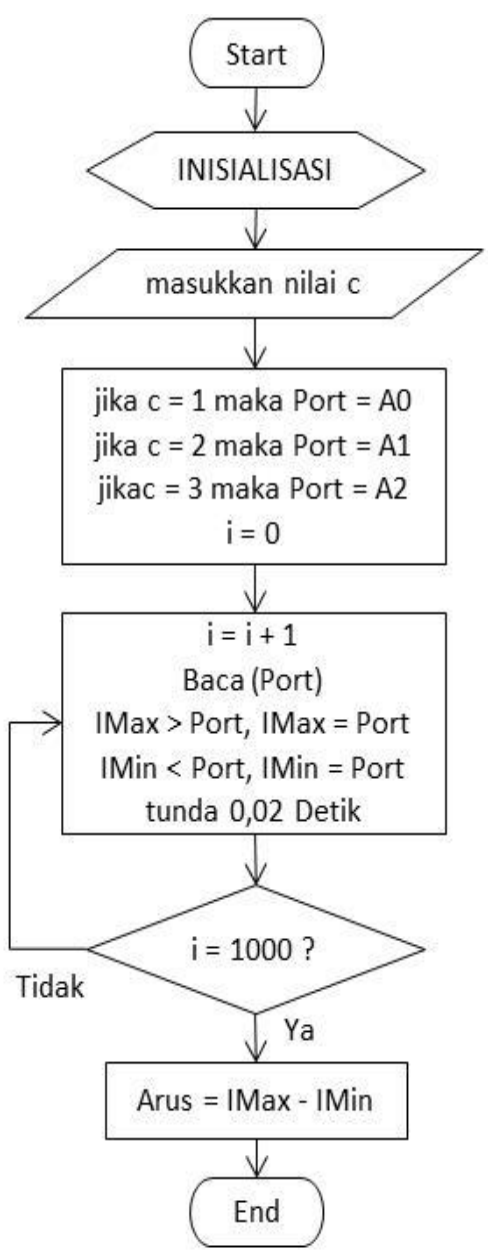

B. Flowchart penditeksi arus

Gambar 4. Flowchart penditeksi ruang kelas dan penditeksi arus

Cara kerja sistem secara keseluruhan diawali dengan pengecekan keadaan ruangan seperti yang ditunjukkan pada Gambar 4(A), setelah sensor PIR tidak mendeteksi pergerakan selama 60 detik dari pergerakan terakhir yang terdeteksi maka sistem melanjutkan ke pengecekan setiap peralatan dalam kelas menggunakan alur seperti yang ditunjukkan pada Gambar 4(B). Jika data sensor arus pada peralatan di dalam kelas terdeteksi melebihi referensi yang telah ditentukan maka sistem akan mematikannya dengan mengirimkan sinyal ON/OFF dari pemancar infra merah untuk mematikan AC dan proyektor, lampu dimatikan dengan mengirimkan sinyal HIGH sehingga membuat relay memutus aliran arus menuju lampu. Dalam penelitian ini menggunakan library IRremote dari https:/github.com/z3t0/Arduino-IRremote untuk memprogram pemancar infra merah dalam mengendalikan AC dan proyektor. Gambar 5 menunjukkan flowchart keseluruhan. 


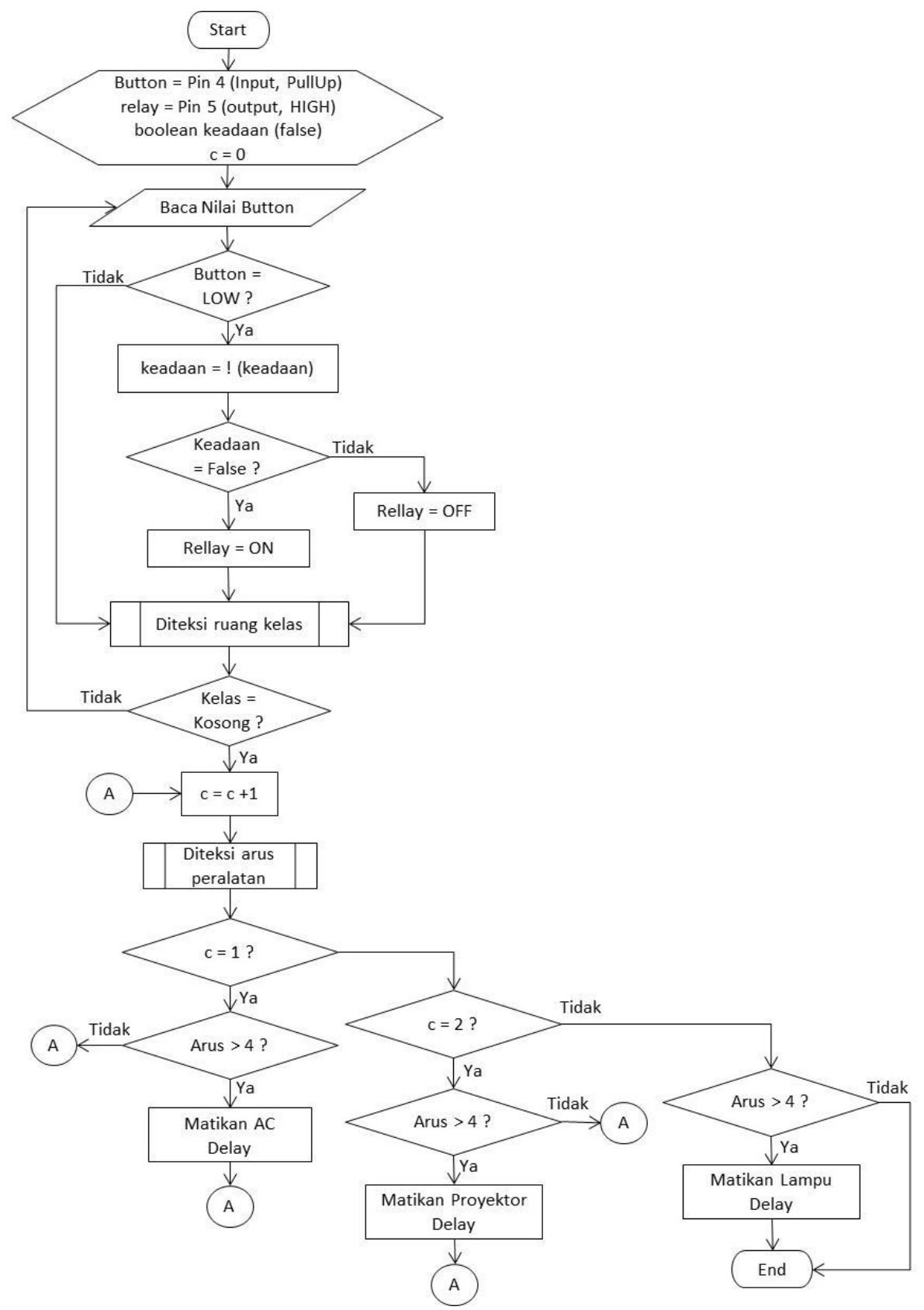

Gambar 5. Flowchart keseluruhan

\subsection{Pengujian dan Analisis}

Pengujian dilakukan terhadap sistem pendeteksi ruangan kelas, sistem pendeteksi arus dan pengujian secara keseluruhan. Pengujian dilakukan dengan menggunakan beban 1 buah lampu LED 10W, mini proyektor $24 \mathrm{~W}$ dan TV LED 24 inch. Proses analisa dilakukan untuk melihat apakah sistem telah berjalan seperti yang direncanakan, apabila hasil belum sesuai dengan yang direncanakan maka proses penelitian ini akan di ulang mulai dari perancangan sistem.

\subsection{Kesimpulan}

Kesimpulan dari penelitian ini akan diambil jika pengujian sistem telah berjalan seperti yang direncanankan. Kesimpulan diambil berdasarkan data hasil pengujian yang telah dianalisis sebagai kesimpulan dari laporan penelitian ini.

\section{HASIL DAN PEMBAHASAN}

Hasil perancangan perangkat keras yang terdiri dari 1 buah sensor PIR, 3 buah sensor SCT-013-030, 2 buah LED infra merah, Arduino Uno, Power Suply dan rangkaian pendukung lainnya dikemas dalam 1 buah kotak yang berukuran $18 \mathrm{~cm}$ x $11 \mathrm{~cm}$ x $6 \mathrm{~cm}$, tampak depan dan isi belakang ditunjukkan pada Gambar 6 . 


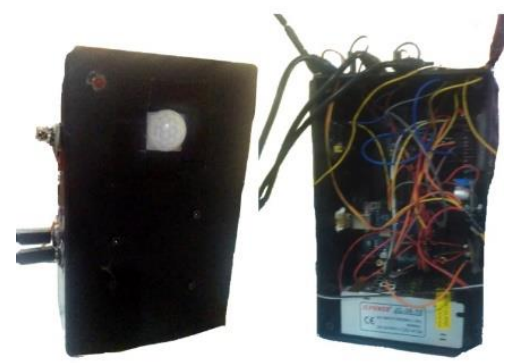

Gambar 6. Hasil perancangan sistem

\subsection{Pengujian Pendeteksi Ruang Kelas}

Sekenario dalam pengujian ini dilakukan seperti flowchart pada Gambar 4(A) dan sistem akan mengirimkan teks "GERAKAN TERDIREKSI" ke serial monitor dan menampilkan waktu (angka mulai menghitung dalam mili detik), dan selama waktu yang telah ditentukan, apabila PIR tidak mendeteksi gerakan, maka sistem akan mengirimkan teks "Tidak ada gerakan !" ke serial monitor serta menampilkan waktu (angka terakhir yang dihitung dalam mili detik). Pengujian dilakukan untuk waktu 10 detik dan 60 detik. Gambar 7 menunjukkan hasil pengujian pendeteksi ruang kelas yang ditampilkan pada serial monitor Arduino.

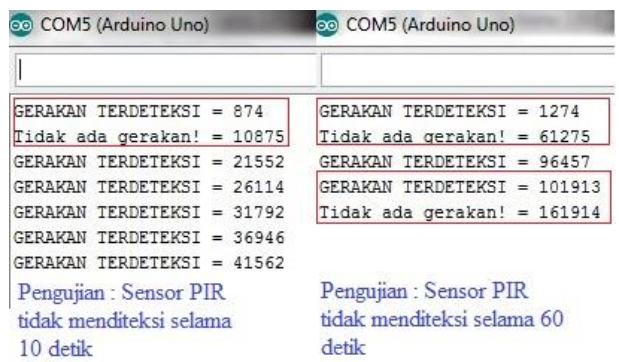

Gambar 7. Pengujian pendeteksi ruang kelas

Dari hasil Pengujian yang ditunjukkan pada Gambar 7, terlihat bahwa sistem telah dapat mendeteksi tidak adanya pergerakan selama 10 detik dan 60 detik. Untuk pendeteksi tidak ada pergerakan selama 10 detik, sistem mendeteksi tidak ada pergerakan setelah cacatan selisih waktu 10001 mili detik dan untuk pendeteksi tidak ada pergerakan selama 60 detik, sistem mendeteksi tidak ada pergerakan setelah cacatan selisih waktu 60001 mili detik. Dari hasil pengujian pendeteksi ruang kelas sistem telah dapat mendeteksi keadaan ruang kelas yang sudah kosong selama 10 detik dan 60 detik dan dapat disimpulkan perancangan sistem pendeteksi ruang kelas telah sesuai dengan perancangan program.

\subsection{Pengujian pendeteksi arus}

Untuk memastikan pembacaan data sensor SCT-013-30 telah berjalan dengan baik, pengujian dilakukan untuk membaca data sensor arus (data ADC) saat peralatan OFF dan ON (Peralatan berupa Labtop dan kipas angin dengan daya $30 \mathrm{~W}$ ) masing-masing untuk 100 data pembacaan. Tabel 1 menunjukkan hasil pengujian pengambilan data sensor SCT-013-030.

Tabel 1. Pengujian sensor SCT-013-030

\begin{tabular}{ccccc}
\hline \multirow{2}{*}{ No } & \multicolumn{2}{c}{ Peralatan OFF } & \multicolumn{2}{c}{ Peralatan ON } \\
& Data Sensor (x) & Jumlah (n) & Data Sensor (x) & Jumlah (n) \\
\hline 1 & 0 & 3 & 13 & 14 \\
2 & 1 & 70 & 14 & 47 \\
3 & 2 & 8 & 15 & 22 \\
4 & 3 & 6 & 16 & 3 \\
5 & 4 & 5 & 17 & 2 \\
6 & 5 & 8 & 18 & 11 \\
7 & - & - & 19 & 1 \\
\hline
\end{tabular}

Untuk keadaan peralatan OFF didapat $\bar{x}=1,64$ dengan Standard Deviation $=1,29$. Untuk keadaan peralatan ON, $\overline{\mathrm{x}}=14,69$ dan Standard Deviation $=1,48$. Sekenario pengujian selanjutnya dengan melakukan pembacaan data arus pada tiga peralatan elektronik, dalam pengujian ini menggunakan TV (sebagai pengganti AC), mini proyektor 24W dan lampu LED 10W dan menggunakan program sesuai dengan Gambar 4(B). Data sensor yang terbaca Port A0, A1, A2 digunakan untuk memberikan nilai referensi pembacaan keadaan peralatan dalam 
JURNAL MEDIA INFORMATIKA BUDIDARMA

Volume 4, Nomor 3, Juli 2020, Page 626-634

ISSN 2614-5278 (media cetak), ISSN 2548-8368 (media online)

Available Online at https://ejurnal.stmik-budidarma.ac.id/index.php/mib

DOI 10.30865/mib.v4i3.2134

keadaan ON/OFF. Tabel 2 menunjukkan hasil pembacaan sensor untuk ketiga peralatan elektronik dalam keadaan OFF/ON dengan Arus Terdeteksi $1=\mathrm{Lampu}$, Arus Terdeteksi $2=$ mini proyektor dan Arus Terdeteksi $3=\mathrm{TV}$

Tabel 2. Hasil pengujian ketiga sensor

\begin{tabular}{ccccccc}
\hline \multirow{2}{*}{ No } & \multicolumn{3}{c}{ Peralatan keadaan OFF } & \multicolumn{3}{c}{ Peralatan Keadaan ON } \\
& Sensor 1 & Sensor 2 & Sensor 3 & Sensor 1 & Sensor 2 & Sensor 3 \\
\hline 1 & 1 & 1 & 2 & 6 & 9 & 11 \\
2 & 2 & 2 & 1 & 5 & 8 & 11 \\
3 & 1 & 1 & 2 & 6 & 8 & 11 \\
4 & 2 & 2 & 1 & 5 & 9 & 11 \\
5 & 1 & 2 & 2 & 5 & 8 & 13 \\
6 & 1 & 2 & 2 & 5 & 8 & 11 \\
Average & 1,333 & 1,667 & 1,667 & 5,333 & 8,333 & 11,333 \\
Standard Deviation & 0,516 & 0,516 & 0,516 & 0,516 & 0,516 & 0,816 \\
\hline
\end{tabular}

Tabel 2 menunjukkan data sensor 1 s.d 3 untuk keadaan peralatan OFF serta data sensor 1 dan sensor 2 saat keadaan peralatan $\mathrm{ON}$ memiliki standard diviation yang sama, yaitu $\mathrm{S}=0,516$. Untuk sensor 3 pada saat peralatan ON memiliki $\mathrm{S}=0,816$.

Dalam penelitian ini data yang terbaca oleh sensor SCT-013-030 tidak di konversi ke dalam satuan Ampere, karena sistem yang dirancang hanya membutuhkan data keadaan peralatan ON/OFF saja. Berdasarkan Tabel 2 , sensor ini telah dapat mendeteksi keadaan peralatan saat OFF dan ON dengan baik.

\subsection{Pengujian Pemancar Infra Merah}

Dalam penelitian ini remote control dirancang hanya mengirimkan sinyal ON/OFF. 2 buah LED infra merah disusun secara parallel digunakan sebagai pemancar dan dihubungkan dengan PIN 3 Arduino uno serta dalam pemrograman menggunakan Library IRremote. Sebelum pengujian pengiriman data ke peralatan elektronik, dilakukan duplikasi code remote pada tombol ON/OFF dahulu dari masing-masing remote control (dalam penelitian ini menggunakan remote TV dan mini proyektor). Untuk dapat mendeteksi code remote dibutuhkan penerima infra merah (dalam penelitian ini menggunakan modul KY022 yang terhubung ke pin 11) dan menggunakan example sketch IRRecvDumpV2. Hasil Capture di serial monitor untuk remote control TV dan remote control mini proyektor ditunjukkan pada Gambar 8 .

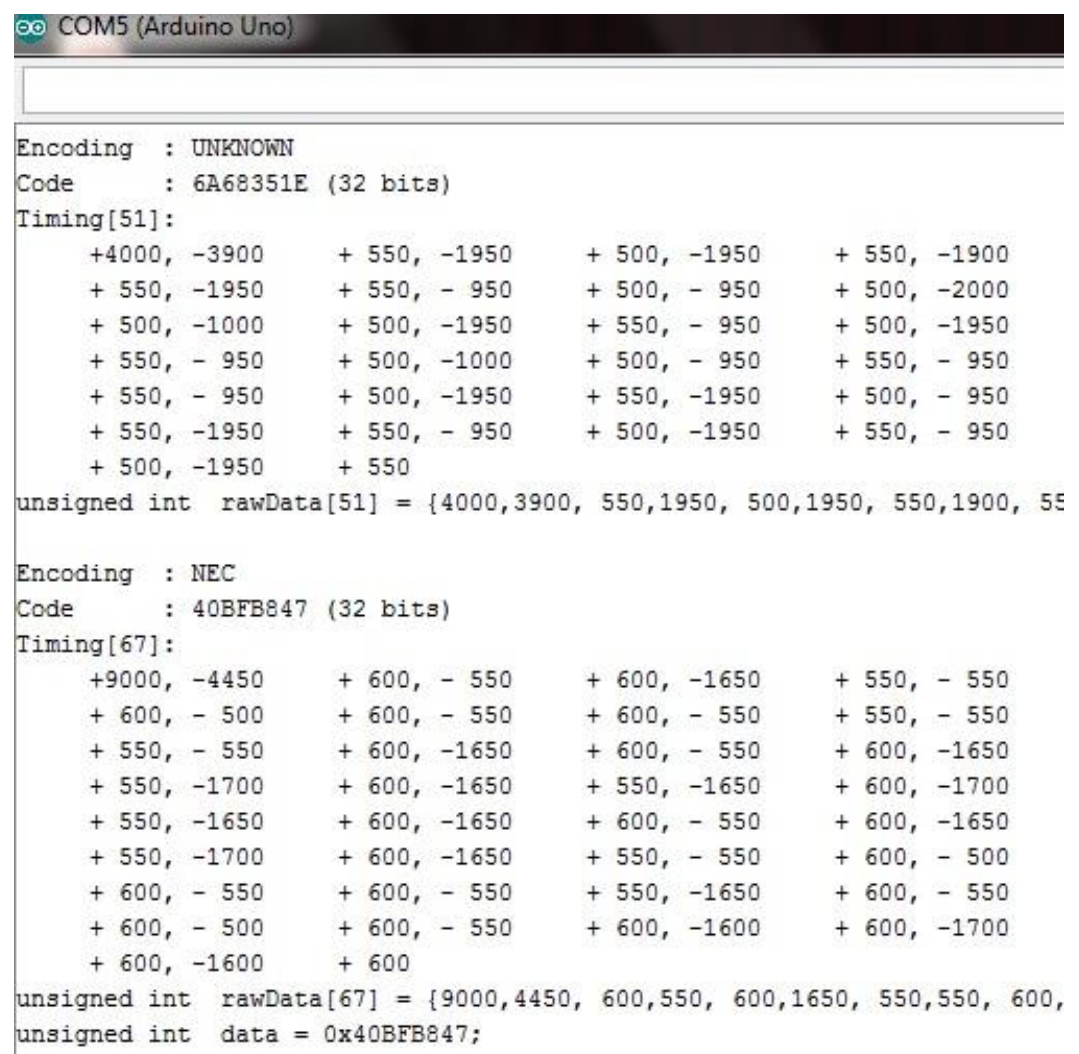

Gambar 8. Code ON/OFF Remote control 
JURNAL MEDIA INFORMATIKA BUDIDARMA

Volume 4, Nomor 3, Juli 2020, Page 626-634

ISSN 2614-5278 (media cetak), ISSN 2548-8368 (media online)

Available Online at https://ejurnal.stmik-budidarma.ac.id/index.php/mib

DOI 10.30865/mib.v4i3.2134

Dari Gambar 8 terlihat bahwa tidak ditemukan code pada Library, maka untuk mengirimkan sinyal ON/OFF TV penulis menggunakan Raw datanya dengan sketch dalam Arduino sebagai berikut :

int $k h z=38$;

unsigned int irSignal $]=\{4000,3900,550,1950,500,1950,550,1900,550,1950,550,950,500,950,500,2000$, $500,1000,500,1950,550,950,500,1950,550,950,500,1000,500,950,550,950,550,950,500,1950,550,1950$, 500,950, 550,1950, 550,950, 500,1950, 550,950, 500,1950, 550\};

irsend.sendRaw(irSignal, sizeof(irSignal) / sizeof(irSignal[0]), khz.

delay(5000);

Dari Gambar 8 terlihat code pada Library, maka untuk mengirimkan sinyal ON/OFF mini proyektor penulis menggunakan sketch dalam Arduino sebagai berikut :

irsend.sendNEC(0x40BFB847, 32);

$\operatorname{delay}(5000)$;

Dari hasil pengujian dengan mengarahkan pemancar infra merah ke penerima infra merah TV dan mini proyektor, sistem telah dapat menghidupkan/ mematikan TV dan mini proyektor dengan menggunakan sketch diatas.

\subsection{Pengujian Sistem Keseluruhan}

Pengujian dilakukan dengan memasang sensor SCT013-030 pada salah satu kabel dari sumber yang terhubung ke peralatan elektronik yang akan dikendalikan. Dalam pengujian ini sensor dijepitkan pada salah satu kabel yang menuju TV, mini proyektor dan lampu. Pengujian sistem keseluruhan ditunjukkan pada Gambar 9.

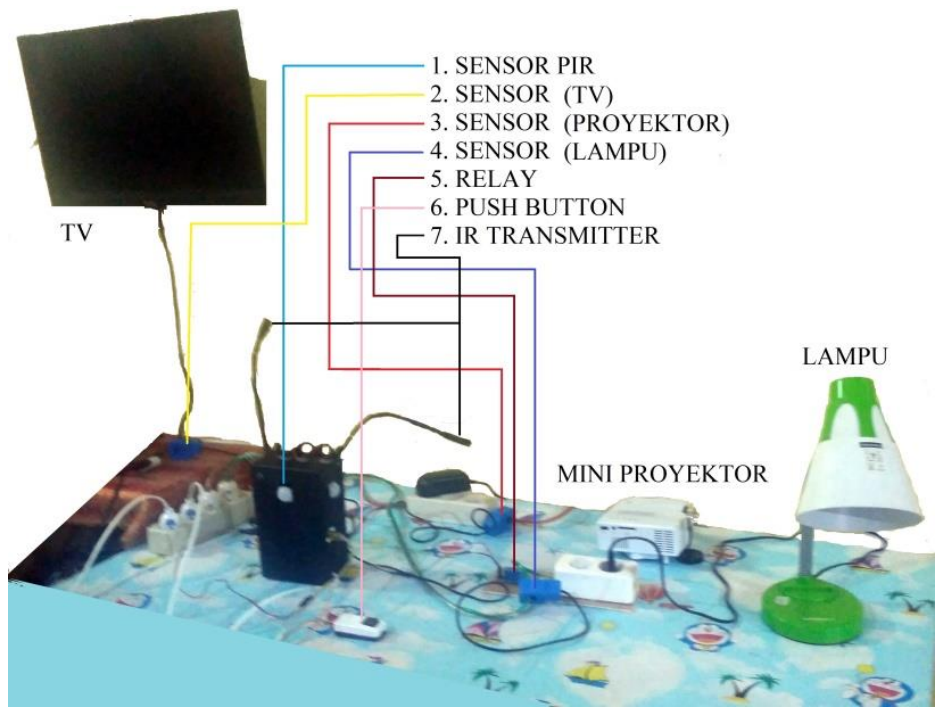

Gambar 9. Pengujian sistem keseluruhan

Pengujian dilakukan dengan memberikan waktu referensi 10 detik, maka sistem akan mematikan peralatan yang masih dalam keadaan hidup jika sensor PIR tidak mendeteksi pergerakan selama waktu referensi yang ditentukan. Hasil pengujian ditunjukkan pada Tabel 3.

Tabel 3. Hasil pengujian sistem keseluruhan

\begin{tabular}{cclllll}
\hline \multirow{2}{*}{ No } & \multicolumn{3}{c}{ Keadaan awal } & \multicolumn{3}{c}{ Keadaan akhir } \\
& TV & Proyektor & Lampu & TV & Proyektor & Lampu \\
\hline 1 & OFF & OFF & OFF & OFF & OFF & OFF \\
2 & OFF & OFF & ON & OFF & OFF & OFF \\
3 & OFF & ON & OFF & OFF & OFF & OFF \\
4 & OFF & ON & ON & OFF & OFF & OFF \\
5 & ON & OFF & OFF & OFF & OFF & OFF \\
6 & ON & OFF & ON & OFF & OFF & OFF \\
7 & ON & ON & OFF & OFF & OFF & OFF \\
8 & ON & ON & ON & OFF & OFF & OFF \\
\hline
\end{tabular}

Dari hasil pengujian terlihat bahwa sistem telah dapat mematikan peralatan secara otomatis, sesuai dengan perancangan sistem. Untuk peralatan yang menggunakan remote control peralatan yang sebelumnya ON setelah 
sensor PIR tidak mendeteksi ada pergerakan selama 10 detik, maka sistem akan mematikan secara otomatis dan untuk keadaan peralatan OFF maka setelah 10 detik sensor tidak mendeteksi pergerakan peralatan tetap dalam keadaan OFF, disini membuktikan bahwa sensor arus telah dapat mendeteksi keadaan peralatan dengan baik.

\section{KESIMPULAN}

Dari hasil pengujian dapatlah diambil kesimpulan :

1. Sistem yang dirancang telah berjalan dengan baik sesuai dengan perancangan sistem, dimana sistem akan mematikan peralatan secara otomatis setelah 10 detik sensor PIR tidak mendeteksi ada pergerakan.

2. Pendeteksi ruang kelas dengan menggunakan sensor PIR telah berjalan dengan baik, hasil pengujian menunjukkan sistem telah dapat mendeteksi tidak ada pergerakan selama waktu yang telah ditentukan. Dalam pengujian ini menggunakan waktu 10 detik dan 60 detik.

3. Pendeteksi arus dengan sensor SCT-013-030 telah dapat mendeteksi keadaan peralatan dalam keadaan ON/OFF. Untuk keadaan OFF rata-rata data sensor lampu $=1,333$, sensor mini proyektor dan $\mathrm{TV}=1,667$. Untuk keadaan peralatan $\mathrm{ON}$ rata-rata data sensor lampu $=5,33$, sensor mini proyektor $=8,333$ dan $\mathrm{TV}=$ 11,333. Standard deviation untuk sensor lampu dan mini proyektor saat peralatan OFF sama dengan peralatan $\mathrm{ON}$ yaitu $\mathrm{S}=0,516$. Standard deviation untuk sensor TV dalam keadaan OFF $\mathrm{S}=0,516$ dan untuk keadaan ON $\mathrm{S}=0,816$.

4. Pengendalian peralatan yang menggunakan remote control menggunakan Library IRremote telah dapat menghidupkan dan mematikan mini proyektor dan TV.

5. Pengujian dilakukan untuk mematikan peralatan elektronik secara otomatis dengan menggunakan peralatan elektronik berupa lampu LED 10W, mini proyektor 24W dan TV LED 24 inch.

\section{UCAPAN TERIMAKASIH}

Penulis mengucapkan terima kasih kepada LPPM Universitas Sriwijaya yang telah mendanai penelitian dalam skim SATEKS ini dengan Nomor Kontrak : 0146.207/UN9/SB3.LP2M.PT/2019.

\section{REFERENCES}

[1] D. H. B. Krisna, S. Sumaryo, and A. S. Wibowo, "Sistem Kelas Pintar Dengan Kontrol Penggunaan Energi Listrik," eProceedings Eng., vol. 5, no. 3, 2018.

[2] I. Riyanto, L. Margatama, H. Hakim, and D. E. Hindarto, "Motion Sensor Application on Building Lighting Installation for Energy Saving and Carbon Reduction Joint Crediting Mechanism," Appl. Syst. Innov., vol. 1, no. 3, p. $23,2018$.

[3] E. Desyantoro, A. F. Rochim, and K. T. Martono, "Sistem Pengendali Peralatan Elektronik Dalam Rumah Secara Otomatis Menggunakan Sensor PIR, Sensor LM35, dan Sensor LDR," J. Teknol. dan Sist. Komput., vol. 3, no. 3, pp. 405-411, 2015.

[4] N. Nabilah et al., "PEMBUATAN PROTOTIPE LAMPU OTOMATIS UNTUK PENGHEMATAN ENERGI BERBASIS ARDUINO UNO DI DEPARTEMEN FISIKA FMIPA IPB," in PROSIDING SEMINAR NASIONAL FISIKA (E-JOURNAL), 2016, vol. 5, pp. SNF2016-CIP.

[5] N. Y. D. Setyaningsih and I. A. Rozaq, "Efisiensi Beban Smart Home (Rumah Pintar) Berbasis Arduino Uno," Pros. SNATIF, pp. 297-302, 2017.

[6] M. P. Lukman, Junaedy, and Y. F. Y. Rieuwpassa, "SISTEM LAMPU OTOMATIS DENGAN SENSOR GERAK, SENSOR SUHU DAN SENSOR SUARA BERBASIS MIKROKONTROLER,” J. Resist. (Rekayasa Sist. Komputer), vol. 1, no. 2, pp. 100-108, 2018.

[7] I. W. Y. Widiana, I. G. A. P. R. Agung, and P. Rahardjo, "RANCANG BANGUN KENDALI OTOMATIS LAMPU DAN PENDINGIN RUANGAN PADA RUANG PERKULIAHAN BERBASIS MIKROKONTROLER ARDUINO NANO," J. SPEKTRUM, vol. 6, no. 2, pp. 112-120, 2019.

[8] I. Marzuki, "Perancangan dan Pembuatan Sistem Penyalaan Lampu Otomatis Dalam Ruangan Berbasis Arduino Menggunakan Sensor Gerak dan Sensor Cahaya," J. INTAKE J. Penelit. Ilmu Tek. Dan Ter., vol. 10, no. 1, pp. 9-16, 2019.

[9] M. I. Kurniawan, U. Sunarya, and R. Tulloh, "Internet of Things: Sistem Keamanan Rumah berbasis Raspberry Pi dan Telegram Messenger," ELKOMIKA J. Tek. Energi Elektr. Tek. Telekomun. Tek. Elektron., vol. 6, no. 1, p. 1, 2018.

[10] A. Fahmi, A. Finawan, and M. Muhaimin, "RANCANG BANGUN SISTEM PENGENDALI RUMAH CERDAS DENGAN INFORMASI UMPAN BALIK BERBASIS INTERNET OF THINGS,” J. Mhs. Tek. ELEKTRO, vol. 3, no. $1,2019$.

[11] A. Young, "NON-INVASIVE SENSOR: YHDC SCT013-000 CT USED WITH ARDUINO. (SCT-013)," 2018. https://www.poweruc.pl/blogs/news/non-invasive-sensor-yhdc-sct013-000-ct-used-with-arduino-sct-013 (accessed Apr. 21, 2020).

[12] L. Beijing YaoHuadechang Electronic Co., "Splilt-core current transformer," 2011. [Online]. Available: http://webmeteobox.ru/docs/SCT013-030V.pdf. 